\title{
Body Mass Index and the Relationship with Chronic Kidney Disease in a Tertiary Care Hospital in Romania
}

\author{
Caldararu Carmen Denise1, Tarta Dorin ${ }^{1 *}$, Pop Raluca², Gliga Mirela1, Carasca Emilian³, Dogaru Grigore ${ }^{1}$ \\ ${ }^{1}$ Department of Nephrology, University of Medicine and Pharmacy Targu Mures, Romania \\ 2 Research Methodology Department, University of Medicine and Pharmacy Targu Mures, Romania \\ 3 Department of Internal Medicine, University of Medicine and Pharmacy Targu Mures, Romania
}

Obesity and chronic kidney disease are epidemic size. Chronic kidney disease (CKD) appears to be more common in obese, although interrelation is not supported by all authors. Aim: The aim of the study was to investigate the effects of overweight and obesity on glomerular filtration rate (GFR) and the relationship between body mass index (BMI) and other risk factors for CKD. Methods: This is a cross-sectional study on 627 patients admitted in a Nephrology Department between January 2007 - December 2011. Patients were divided according to eGFR in a CKD group and a non-CKD group. Patients were divided based on BMl in: normal ( $<25 \mathrm{~kg} / \mathrm{m} 2)$, overweight ( $\geq 25 \mathrm{~kg} / \mathrm{m} 2 \mathrm{and} \leq 30 \mathrm{~kg} /$ $\mathrm{m} 2)$ and obese (>30 kg/m2). Demographical, clinical and laboratory data (serum creatinine, lipid parameters, etc) were used for the statistical analysis. The relationship between BMI (as a marker of obesity and overweight), glomerular filtration rate and other possible risk factors for chronic kidney disease was studied. Results: $43.70 \%$ patients were obese and 33.17\% overweight. CKD prevalence was 58.69\%. Logistic regression analysis showed that systolic blood pressure was the main determinant of CKD in our patients. Conclusion: Lack of association between BMI and CKD was demonstrated in our study.

Keywords: chronic kidney disese, body mass index, obesity

Received: 31 December 2015 / Accepted: 21 March 2016

\section{Introduction}

Chronic kidney disease (CKD) is recognized as an important healthcare problem, with increasing prevalence and pandemic size $[1,2]$.

The potential relationship between chronic kidney disease and obesity was postulated by a large number of experimental and epidemiologic studies and is a subject of wide debate. There are many pathways by which obesity may contribute to renal disease: hormonal factors, increased sympathetic activity, proinflammatory state, lipid disturbances, hemodynamic factors [3-7].

This relationship was found in the general population but studies are conflicting and difficult to compare taking into consideration that they relate to different races, different populations and different markers used to quantify obesity $[8,9]$

Preventing CKD and obesity and clarifying the relationship between them is an important task for current medicine because both obesity as well as chronic kidney disease confers an extremely high risk for cardiovascular morbidity and mortality and additional costs for health care systems $[10,11]$.

The aim of this study was to investigate the relationship between BMI, chronic kidney disease and other risk factors for CKD in a population of patients with a high prevalence of chronic kidney disease.

* Correspondence to: Dorin Tarta

E-mail: nefrologie@yahoo.ro

\section{Methods}

This cross-sectional study was performed in the Nephrology Department of Mures County Clinical Hospital from January 2007 to December 2011. All patients addmitted who had available data on body weight, blood pressure (BP) values, lipid profile, serum creatinine and glucose were included in the study.

The study was approved by the local Ethics Committee.

Body mass index was calculated with the formula $\mathrm{BMI}=\mathrm{kg} / \mathrm{m}^{2}$. Patients were divided based on BMIs in three groups: normal $\left(<25 \mathrm{~kg} / \mathrm{m}^{2}\right)$, overweight $\left(\geq 25 \mathrm{~kg} / \mathrm{m}^{2}\right.$ and $\left.\leq 30 \mathrm{~kg} / \mathrm{m}^{2}\right)$ and obese $\left(>30 \mathrm{~kg} / \mathrm{m}^{2}\right)$

eGFR was calculated using the four-variable Modification of Diet in Renal Disease Study equation (MDRD). All subjects with eGFR $<60 \mathrm{ml} / \mathrm{min} / 1.73 \mathrm{~m}^{2}$ were included in the chronic kidney disease (CKD) group.

Statistical analysis. Data are presented as the mean \pm $\mathrm{SD}$ for continuous variables and as proportions for categorical variables. Categorical variables were analyzed using chi-squared test. T test and one-way analysis of variance (ANOVA) was used to test the continuous variables between single and multiple groups, respectively. A value of $\mathrm{p}<0.05$ was considered of statistical significance.

The association between obesity, $\mathrm{CKD}$, and other possible risk factors for kidney disease was analysed using multiple regression and logistic regression analysis.

Two multiple regression analysis models using CKD as dependend variable were studied. In the first model age and BMI were independent variables. The second model was adjusted for BMI, systolic blood pressure and gender. 
For both genders, two multiple regression analysis were studied. In the first model age and BMI were independent variables. The second model was adjusted for BMI, systolic blood pressure, blood glucose and total cholesterol.

Logistic regression analysis with $\mathrm{CKD}$ as a dependent variable and BMI, age, and systolic blood pressure as covariates, was used in order to establish the significance of each factor for CKD.

\section{Results}

A total of 627 Caucasian patients (mean age $57.73 \pm 14.31$ years, mean BMI $29.56 \pm 6.051 \mathrm{~kg} / \mathrm{m}^{2}$ ) were studied; $43.70 \%$ of them were obese and $33.17 \%$ were overweight.

The prevalence rate of chronic kidney disease was $58.69 \%$ (174 females and 194 males).

Table I. Baseline clinical, laboratory and demographic data

\begin{tabular}{lc}
\hline Parameter & Mean \pm SD \\
\hline Age $($ years $)$ & $57.73 \pm 14.31$ \\
BMI $(\mathrm{kg} / \mathrm{m} 2)$ & $29.56 \pm 6.051$ \\
eGFR $(\mathrm{ml} / \mathrm{min} / 1.73 \mathrm{~m} 2)$ & $53.15 \pm 32.79$ \\
Systolic blood pressure $(\mathrm{mmHg})$ & $137.8 \pm 21.51$ \\
Blood glucose $(\mathrm{mg} / \mathrm{dl})$ & $115.5 \pm 50.87$ \\
Hemoglobin $(\mathrm{g} / \mathrm{dl})$ & $12.28 \pm 2.317$ \\
Serum urea $(\mathrm{mg} / \mathrm{dl})$ & $69.78 \pm 52.12$ \\
Total cholesterol $(\mathrm{mg} / \mathrm{dl})$ & $198.3 \pm 69.28$ \\
Serum triglycerides $(\mathrm{mg} / \mathrm{dl})$ & $182.6 \pm 143.4$ \\
Cholesterol HDL $(\mathrm{mg} / \mathrm{dl})$ & $45.36 \pm 17.07$ \\
Serum albumins $(\mathrm{g} / \mathrm{l})$ & $41.71 \pm 19.52$ \\
Serum proteins $(\mathrm{g} / \mathrm{dl})$ & $6.617 \pm 0.9116$ \\
24h urinary proteins $(\mathrm{g} / 24 \mathrm{~h})$ & $1.307 \pm 2.163$ \\
\hline
\end{tabular}

Chronic kidney disease etiology was diabetes nephropathy in $22.01 \%$ of cases, glomerular diseases in $19.83 \%$, tubulointerstitial diseases in $25.00 \%$, polycystic kidney disease in $2.98 \%$ and other causes in $17.11 \%$.

Clinical characteristics of study subjects are presented in table I.

When analyzing patients grouped according to BMI values, we found that the higher BMI group have significant higher age, serum glucose, total cholesterol, triglycerides, serum proteins and hemoglobin and low values of cholesterol HDL (Table II).

No significant relationship between BMI groups and eGFR or the presence of CKD was found.

BMI was not found to be significantly correlated with eGFR in linear regression analysis.

Multiple regression analysis using CKD as dependent variable showed no association with BMI, but a significant association with age (model $1, \mathrm{p}<0.05$, Table III) and systolic blood pressure (model 2, $\mathrm{p}<0.05$, Table III).

For both genders, CKD showed no relationship with BMI. Age and systolic blood pressure was associated with $\mathrm{CKD}$ in females and systolic blood pressure was associated with CKD in males (Table IV, V).

Logistic regression analysis using CKD as a dependent variable and $\mathrm{BMI}$, age and systolic blood pressure as independent covariates showed that systolic blood pressure was the main determinant of CKD in our patients (Table VI).

Table II. Comparative study of anthropometric, clinical and laboratory parameters in normal BMI, overweight and obese patients

\begin{tabular}{|c|c|c|c|c|}
\hline & $\begin{array}{c}\mathrm{BMl}<25 \mathrm{~kg} / \mathrm{m} 2 \\
\text { Mean } \pm \mathrm{SD}\end{array}$ & $\begin{array}{c}\mathrm{BMl} \geq 25 \mathrm{~kg} / \mathrm{m} 2 \text { and } \leq 30 \mathrm{~kg} / \mathrm{m} 2 \\
\text { Mean } \pm \mathrm{SD}\end{array}$ & $\begin{array}{c}\mathrm{BMl}>30 \mathrm{~kg} / \mathrm{m} 2 \\
\text { Mean } \pm \mathrm{SD}\end{array}$ & $\mathrm{p}$ \\
\hline Age (years) & $53.24 \pm 17.47$ & $58.21 \pm 14.93$ & $59.74 \pm 11.17$ & $<0.0001$ \\
\hline Females (N /\%) & $73 / 50.34 \%$ & $93 / 44.71 \%$ & $162 / 59.12 \%$ & $<0.05$ \\
\hline Blood glucose (mg/dl) & $106.4 \pm 52.51$ & $112.4 \pm 51.70$ & $122.2 \pm 48.71$ & $<0.05$ \\
\hline eGFR (ml/min/1.73 m2) MDRD & $51.75 \pm 37.64$ & $53.73 \pm 33.14$ & $53.46 \pm 29.74$ & NS \\
\hline Hemoglobin (g/dl) & $11.53 \pm 2.297$ & $12.46 \pm 2.491$ & $12.56 \pm 2.097$ & $<0.0001$ \\
\hline Total cholesterol (mg/dl) & $190.0 \pm 70.96$ & $205.0 \pm 84.61$ & $197.7 \pm 53.40$ & NS \\
\hline Serum triglycerides (mg/dl) & $147.5 \pm 89.59$ & $187.5 \pm 187.3$ & $197.5 \pm 124.9$ & $<0.05$ \\
\hline Cholesterol HDL (mg/dl) & $50.44 \pm 20.40$ & $45.30 \pm 16.51$ & $42.65 \pm 14.85$ & $<0.05$ \\
\hline Serum proteins (g/dl) & $6.371 \pm 0.9160$ & $6.640 \pm 1.047$ & $6.744 \pm 0.7564$ & $<0.05$ \\
\hline Serum albumins $(\mathrm{g} / \mathrm{l})$ & $39.30 \pm 6.466$ & $44.01 \pm 31.29$ & $40.99 \pm 7.603$ & NS \\
\hline Fibrinogen (mg/dl) & $458.1 \pm 165.4$ & $461.9 \pm 192.2$ & $485.0 \pm 157.4$ & NS \\
\hline $24 \mathrm{~h}$ urinary proteins $(\mathrm{g} / 24 \mathrm{~h})$ & $1.495 \pm 1.772$ & $1.282 \pm 2.597$ & $1.217 \pm 1.979$ & NS \\
\hline CKD (YES/NO) & $90 / 55$ & $115 / 93$ & $163 / 111$ & NS \\
\hline
\end{tabular}

Table III. Multiple regression analysis models for all patients

\begin{tabular}{|c|c|c|c|c|c|c|}
\hline \multirow[b]{2}{*}{ Model 1} & \multirow[b]{2}{*}{ (Constant) } & \multicolumn{2}{|c|}{ 95.0\% Confidence Interval } & \multirow{2}{*}{$\frac{t}{3.275}$} & \multirow{2}{*}{$\frac{p}{0.001}$} & \multirow[t]{2}{*}{ Colinearity statistics (VIF) } \\
\hline & & 0.152 & 0.608 & & & \\
\hline & AGE & 0.002 & 0.008 & 3.465 & 0.001 & 1.032 \\
\hline & BMI & -0.009 & 0.004 & -0.728 & 0.467 & 1.032 \\
\hline \multirow[t]{4}{*}{ Model 2} & (Constant) & -0.354 & 0.237 & -0.391 & 0.696 & \\
\hline & BMI & -0.007 & 0.005 & -0.307 & 0.759 & 1.024 \\
\hline & SEX & -0.179 & -0.027 & -2.663 & 0.008 & 1.025 \\
\hline & SBP & 0.004 & 0.007 & 5.918 & 0.000 & 1.018 \\
\hline
\end{tabular}


Table IV. Multiple regression analysis models in men

\begin{tabular}{|c|c|c|c|c|c|c|}
\hline \multirow[b]{2}{*}{ Model 1} & \multirow[b]{2}{*}{ (Constant) } & \multicolumn{2}{|c|}{ 95.0\% Confidence Interval } & \multirow{2}{*}{$\begin{array}{c}\mathrm{t} \\
2.556\end{array}$} & \multirow{2}{*}{$\begin{array}{c}\mathrm{p} \\
0.011\end{array}$} & \multirow[t]{2}{*}{ Colinearity statistics (VIF) } \\
\hline & & 0.454 & 0.177 & & & \\
\hline & AGE & 0.003 & 0.002 & 1.787 & 0.075 & 1.012 \\
\hline & BMI & 0.000 & 0.005 & -0.028 & 0.977 & 1.012 \\
\hline \multirow[t]{5}{*}{ Model 2} & (Constant) & -0.238 & 0.760 & 1.030 & 0.304 & \\
\hline & BMI & -0.005 & 0.015 & 0.968 & 0.334 & 1.028 \\
\hline & SBP & 0.001 & 0.007 & 2.803 & 0.005 & 1.027 \\
\hline & GLU & -0.003 & 0.000 & -2.612 & 0.010 & 1.048 \\
\hline & $\mathrm{CHOL}$ & -0.001 & 0.000 & -1.984 & 0.048 & 1.009 \\
\hline
\end{tabular}

Legend: BMI - body mass index, SBP - systolic blood pressure, GLU - plasma glucose, $\mathrm{CHOL}$ - total cholesterol

Table V. Multiple regression analysis models in woman

\begin{tabular}{|c|c|c|c|c|c|c|}
\hline \multirow[b]{2}{*}{ Model 1} & \multirow[b]{2}{*}{ (Constant) } & \multicolumn{2}{|c|}{$95.0 \%$ Confidence Interval } & \multirow{2}{*}{$\begin{array}{c}\mathrm{t} \\
1.742\end{array}$} & \multirow{2}{*}{$\begin{array}{c}p \\
0.082\end{array}$} & \multirow[t]{2}{*}{ Colinearity statistics (VIF } \\
\hline & & -0.035 & 0.571 & & & \\
\hline & AGE & 0.002 & 0.010 & 2.908 & 0.004 & 1.058 \\
\hline & BMI & -0.011 & 0.006 & -0.500 & 0.617 & 1.058 \\
\hline \multirow[t]{5}{*}{ Model 2} & (Constant) & -0.895 & 0.014 & -1.909 & 0.057 & \\
\hline & BMI & -0.011 & 0.006 & -.563 & 0.574 & 1.066 \\
\hline & SBP & 0.005 & 0.010 & 5.270 & 0.000 & 1.065 \\
\hline & GLU & -0.001 & 0.001 & 0.255 & 0.799 & 1.031 \\
\hline & $\mathrm{CHOL}$ & -0.001 & 0.001 & 0.497 & 0.619 & 1.016 \\
\hline
\end{tabular}

Legend: BMI - body mass index, SBP - systolic blood pressure, GLU - plasma glucose, $\mathrm{CHOL}$ - total cholesterol

Table VI. Logistic regression analysis with age and systolic blood pressure as independent variables

\begin{tabular}{ccccc}
\hline Variable & Coefficient & Std. Error & Odds ratio & P5\% Cl \\
\hline SBP & 0.023737 & 0.0043666 & 1.0240 & 1.0153 to 1.0328 \\
AGE & 0.014977 & 0.0059596 & 1.0151 & 1.0033 to 1.0270 \\
CKD & -3.7457 & & & 0.0120 \\
\hline Legend: SBP - systolic blood pressure, CKD - chronic kidney disease & & &
\end{tabular}

Legend: SBP - systolic blood pressure, CKD - chronic kidney disease

\section{Discussion}

Obesity and chronic kidney disease are becoming a worldwide epidemic. Both entities are associated with an enormous risk of cardiovascular disease and mortality.

Previous studies demonstrated that higher BMI was significantly associated with increased risk for $\mathrm{CKD}$. In a large cohort of 11104 initially healthy men, Gelber et al showed that BMI was associated significantly with increased risk for CKD after 14 years of follow-up [12].

Ejerblad et al calculated that overweight (BMI $>25 \mathrm{~kg} /$ $\mathrm{m}^{2}$ ) at age 20 was associated with a significant three-fold excess risk for chronic renal failure, relative to $\mathrm{BMI}<25 \mathrm{~kg} /$ $\mathrm{m}^{2}$ [13]. In a recent study made on a population screened for the presence of diabetes, increasing obesity measured by BMI was associated with a reduction in eGFR [14]. In a population-based, cross-sectional study of a Japanese community, Nomura et al found that BMI was a significant parameter independently correlated with CKD [15].

Some authors showed that the relationship is characterized by a gender difference.

Ishizaka et al showed that overweight and obesity are associated with low eGFR only in men in a group of 8168 Japanese subjects [16]. Similar results are reported by Shankar et al ${ }^{8}$.

On the contrary, Wang and Komura find that obesity increases the risk for $\mathrm{CKD}$ in the general population and the association appears to be stronger in women than in men $[17,18]$.

Our aim was to investigate the relationship between BMI (as a measure of overweight and obesity) and glomerular filtration rate in a population with high prevalence of CKD. The major finding of our study is that high BMI showed no clear association with CKD.

Our findings are consistent with previous studies of Brown et al where the association between obesity and the progression rate of chronic kidney disease was not demonstrated [19] and of Munkhaugen J et al who showed that the risk for CKD did not increase with increasing BMI in patients with normal blood pressure values [20].

Previous studies who investigated the association between chronic kidney disease and metabolic syndrome showed that BMI and abdominal obesity demonstrated little association with $\mathrm{CKD}$ after adjusting for possible confounders [6,21].

When analyzing patients grouped according to BMI values, we found significant differences between those with normal BMI and the overweight or obese subjects. The latter have significant higher age, serum glucose, triglycerides, serum proteins and hemoglobin and low values of cholesterol HDL. We have not shown statistically significant differences in terms of systolic blood pressure and glomerular filtration rate for the three groups of patients. 
The relationship between obesity, triglycerides and HDL cholesterol was mentioned before and a possible explanation is genetics [22,23].

Some evidences about a correlation between obesity and high hemoglobin values exists, even if even if the relationship is not supported by all studies [24,25].

Patients with high body mass index had higher values for total serum proteins. It is possible that the link between the two parameters to be chronic inflammation, but our study did not show significantly higher values of inflammatory markers in patients with overweight and obesity [26].

In our patients systolic blood pressure and age are the parameters who correlates with chronic kidney disease $(\mathrm{OR}=1.0240$, respectively $\mathrm{OR}=1.0151$, Table VI $)$.

The progressive decrease in glomerular filtration rate with increasing age is well known [27] and is also present in our patients. The effect of aging on kidney function appears to be stronger in men [28].

Previous studies and clinical trials are in agreement supporting that hypertensive patients have an elevated risk of $\mathrm{CKD}$, especially if other metabolic conditions are present [29]. The relationship between hypertension and CKD has been shown to be stronger in men [30].

Hypertension is also a consequence of renal disease. The retrospective design of the present study does not allow us to establish clear if kidney damage is the cause or the consequence of hypertension.

In our study the percentage of patients with chronic kidney disease and also the number of overweight and obese patients is remarkable high compared with other studies. Selection bias may represent one answer for our results: the study was conducted on hospitalized patients, in a department where a high percentage of patients had chronic renal impairment.

The large percentage of overweight and diabetic patients may be explained, at least in part, by hypoproteic regimen recommended in chronic kidney disease. Lower protein intake is followed by an increase in the amount of carbohydrates and lipids in the diet, which may result in obesity.

Increased age and sedentary lifestyle can exacerbate this phenomenon. In our study, the group with BMI above 25 $\mathrm{kg} / \mathrm{m}^{2}$ showed statistically significantly higher mean age compared with normal weight patients.

The main limitations of this study are: the retrospective design which does not allow causality assessment, using BMI as the single marker of obesity [31-34], single serum creatinine measurement and the use of MDRD formula for estimation of GFR with possible misclassification of patients with eGFR close to $60 \mathrm{ml} / \mathrm{min} / 1.73 \mathrm{mp}$ [35].

In conclusion, our study demonstrate that obesity assessed by body mass index showed no clear association with CKD.

\section{Conflict of interest}

None to declare.

\section{References}

1. Ogden CL, Caroll MD, Curtin LR, et al. Will all Americans become overweight or obese? Estimating the progression and cost of the US obesity epidemic. JAMA 2006; 295:1549-55.

2. Kambham N, Markowitz GS, Valeri AM, et al. Obesity-related glomerulopathy: an emerging epidemic. Kidney Int 2001;59:1498-509.

3. daSilva AA, doCarmo J, Dubinion J, Hall JE. The role of the sympathetic nervous system in obesity-related hypertension. Curr Hypertens Rep 2009;11:206-11.

4. Zoccali C, Mallamaci F. Obesity, diabetes, adiponectin and the kidney: a podocyte affair. Nephrol Dial Transplant 2008; 23:3767-3770.

5. Gotoh K, Inoue M, Masaki T, et al. Obesity-related chronic kidney disease is associated with spleen-derived IL-10. Nephrol Dial Transplant. 2013; 28:1120-130.

6. Jang SY, Kim $\Perp$, Ju EY, et al. Chronic kidney disease and metabolic syndrome in a general Korean population: the Third Korea National Health and Nutrition Examination Survey (KNHANES III) Study. J Public Health 2010;32:538-46.

7. Wahba IM, Mak RH. Obesity and obesity-initiated metabolic syndrome: mechanistic links to chronic kidney disease. Clin J Am Soc Nephrol. 2007;2:550-62.

8. Shankar A, Leng C, Chial KS, et al. Association between body mass index and chronic kidney disease in men and women: population-based study of Malay adults in Singapore. Nephrol Dial Transplant 2008;23:1910-18.

9. Fox CS, Larson MG, Leip EP, et al. Predictors of new-onset kidney disease in a community-based population. JAMA 2004;291:844-50.

10. Grieve E, Fenwick E, Yang HC, Lean M. The disproportionate economic burden associated with severe and complicated obesity: a systematic review. Obes Rev 2013;14:883-97.

11. Braun L, Sood V, Hogue S, et al. High burden and unmet patient needs in chronic kidney disease. Int J Nephrol Renovasc Dis 2012;5:151-63.

12. Gelber RP, Kurth T, Kausz AT, et al. Association between body mass index and CKD in apparently healthy men. Am J Kidney Dis 2005;46:871-80.

13. Ejerblad E, Fored CM, Lindblad $P$, et al. Obesity and risk for chronic renal failure. J Am Soc Nephrol. 2006;17:1695-702.

14. Burton JO, Gray LJ, Webb DR, et al. Association of anthropometric obesity measures with chronic kidney disease risk in a non-diabetic patient population. Nephrol Dial Transplant. 2012;27:1860-66.

15. Nomura I, Kato J, Kitamura K. Association between body mass index and chronic kidney disease: A population-based, cross-sectional study of a Japanese community. Vasc Health Risk Manag 2009;5:315-20.

16. Ishizaka N, Ishizaka Y, Toda El, Koike K, Seki G, Nagai R, Yamakado M. Association between obesity and chronic kidney disease in Japanese: differences in gender and hypertensive status? Hypertens Res 2007;30:1059-64.

17. Wang $Y$, Chen $X$, Song $Y$, et al. Association between obesity and kidney disease: a systematic review and meta-analysis. Kidney Int 2008;73:1933.

18. Komura H, Nomura I, Kitamura K, et al. Gender difference in relationship between body mass index and development of chronic kidney disease. BMC Res Notes 2013;6:463.

19. Brown RN, Mohsen A, Green D, et al. Body mass index has no effect on rate of progression of chronic kidney disease in non-diabetic subjects. Nephrol Dial Transplant 2012;27:2776-80.

20. Munkhaugen J, Lydersen S, Wideroe TE, Hallan S. Prehypertension, obesity, and risk of kidney disease: 20-year follow-up of the HUNT I study in Norway. Am J Kidney Dis 2009;54:638-46.

21. Gomez P, Ruilope LM, Barrios V, et al. Prevalence of renal insufficiency in individuals with hypertension and obesity/ overweight: The FATH Study. J Am Soc Nephrol 2006;17(12Suppl3):S194-S200.

22. Popruk S, Tungtrongchitr R, Pongpaew $P$, et al. Relationship between soluble leptin receptor, leptin, lipid profiles and anthropometric parameters in overweight and obese Thai subjects. J Med Assoc Thai 2005;88:22027

23. Ogawa T, Hirose $H$, Yamamoto $Y$, et al. Relationships between serum soluble leptin receptor level and serum leptin and adiponectin levels, insulin resistance index, lipid profile, and leptin receptor gene polymorphisms in the Japanese population. Metabolism 2004;53:879-85.

24. Zhang $Y, M a A Q$, Gong $M$, et al. Red blood cell level is increased in obese but not in non-obese patients with coronary heart disease. J Geriatr Cardiol 2010;7:143-46.

25. Qin $Y$, Melse-Boonstra A, Pan X, et al. Anemia in relation to body mass index and waist circumference among chinese women. Nutrition Journal 2013;12:1-3.

26. Wärnberg J, Nova E, Moreno LA, et al. Inflammatory proteins are related to total and abdominal adiposity in a healthy adolescent population: the 
AVENA Study 1,2,3. Am J Clin Nutr 2006;84:505-12.

27. Coresh J, Astor BC, Greene T, et al. Prevalence of chronic kidney disease and decreased kidney function in the adult US population: Third National Health and Nutrition Examination Survey. Am J Kidney Dis. 2003;41:112.

28. Haroun M, Jaar BG, Hoffman SC, et al. Risk factors for chronic kidney disease: a prospective study of 23,534 men and women in Washington County, Maryland. J Am Soc Nephrol 2003;14:2934-41.

29. Weycker D, Nichols GA, O Keeffe-Rosetti M, et al. Risk of chronic kidney disease in hypertensive patients with other metabolic conditions. Journal of Human Hypertension 2008;22:132-34.

30. Yano Y, Fujimoto S, Sato $Y$, et al. Association between prehypertension and chronic kidney disease in the Japanese general population. Kidney Int 2012;81:293-99.
31. Cuppari L. Diagnosis of obesity in chronic kidney disease: BMl or body fat? Nephrol Dial Transplant 2013;28:119-21.

32. Elsayed EF, Sarnak MJ, Tighiouart H, et al. Waist-to-hip ratio, body mass index, and subsequent kidney disease and death. Am J Kidney Dis 2008; 52:29-38.

33. Vupputuri S, Fox CS, Coresh J, et al. Differential estimation of CKD using creatinine- versus cystatin C-based estimating equations by category of body mass index. Am J Kidney Dis 2009;53:993-1001.

34. Silva MIB, Vale BS, Lemos CCS, Torres MRSG, Bregman R. Body adiposity index assess body fat with high accuracy in nondialyzed chronic kidney disease patients. Obesity 2013;21:546-52.

35. Aggarwal N, Porter AC, Tang IYST, Becker BN, Akkina SK. Creatininebased estimations of kidney function are unreliable in obese kidney donors. J Transplant 2012;1-5. 